Magdalena Heruday-Kiełczewska

(Uniwersytet im. Adama Mickiewicza w Poznaniu)

dr, m_heruday@yahoo.com

ORCID iD: 0000-0002-3938-721X

\title{
Materiały dotyczące Powszechnej Wystawy Krajowej w 1929 r. w zbiorach Wielkopolskiej Biblioteki Cyfrowej
}

Wyczekiwane przez Polaków odzyskanie niepodległości w 1918 r. było wydarzeniem, które w kolejnych latach starano się upamiętniać. Było ono na tyle silnym doświadczeniem, że doprowadziło w końcu do pojawienia się pomysłu urządzenia powszechnej wystawy, która miałaby nie tylko wpisać się w nurt upamiętnienia, ale przede wszystkim być projekcją teraźniejszości.

Pomysł wystawy pojawił się $\mathrm{w}$ podobnym czasie w Warszawie i w Poznaniu. Jej celem miało być ukazanie dziesięcioletniego dorobku odrodzonej Polski i pracy, jaką państwo musiało wykonać na wszystkich polach. Gdy okazało się, że Warszawa nie będzie w stanie zbudować odpowiedniej, wystawowej infrastruktury na 1928 r., wyzwanie podjął Cyryl Ratajski, prezydent Poznania ${ }^{1}$ Poprosił Stanisława Wachowiaka, dawnego pracownika Ministerstwa byłej Dzielnicy Pruskiej i byłego wojewodę pomorskiego, o pokierowanie pracami nad wystawą. Zmontowany został następnie Tymczasowy Komitet Organizacyjny, który z czasem przekształcił się w Towarzystwo Powszechna Wystawa Krajowa w 1929 r. w Poznaniu. Towarzystwo miało Radę Główną, na której czele stał Ratajski, oraz Zarząd, którym kierował Naczelny Dyrektor - Wachowiak. Towarzystwo dzieliło się na wydziały, a te jeszcze na komisje ${ }^{2}$. Zaangażowani w budowę wystawy byli ponadto wybitni przedstawiciele życia społecznego, gospodarczego, kulturalnego z Poznania i innych stron Polski ${ }^{3}$.

${ }^{1}$ P. Litewka, Powszechna Wystawa Krajowa (16 maja - 30 września 1929), cz. 1, „Kronika Miasta Poznania" 1979, nr 2, s. 38.

2 S. Wachowiak, Rys historyczny, [w:] Powszechna Wystawa Krajowa w Poznaniu w roku 1929, dzieło zbiorowe pod kierownictwem S. Wachowiaka, t. I, Poznań 1930, s. 14-15.

${ }^{3}$ S. Wachowiak, Czasy, które przeżyłem, Warszawa 1991, s. 115-118. 
Obszar wystawy podzielono na pięć terenów: „A" - gdzie prezentowano główne gałęzie przemysłu (ciężki, metalowy, włókienniczy, elektryczny), zlokalizowany między ul. Grunwaldzką a ul. Głogowska; „B” - poświęcony rządowi, poszczególnym ministerstwom, sztuce, wychowaniu fizycznemu, samorządom, Bankowi Polskiemu, który zajmował przestrzeń w budynkach Collegium Chemicum (Pałac Rządowy) i Collegium Anatomicum (Pałac Sztuki $)^{4}$ i wokół nich; teren „C" stanowił Park Wilsona, gdzie znajdowały się: palmiarnia, pawilon pracy kobiet, pawilon Bogusława Herse, prasa, przemysł muzyczny, Polska współczesna i uzdrowiska; „D” był terenem najmniejszym powierzchniowo i mieścił: pawilon rzemiosła, punkt sanitarny i bazary; w części „E” zaprezentowano pozostałe gałęzie przemysłu i rolnictwo ${ }^{5}$.

Wystawę uroczyście otworzył prezydent Ignacy Mościcki. Do 30 września 1929 r., kiedy została oficjalnie zamknięta, zwiedziło ją 4,5 mln osób z kraju i zagranicy. Większość pawilonów rozebrano, kilka budynków jednak pozostało i pomagają one wyobrazić sobie, jaki rozmach miała Powszechna Wystawa Krajowa.Spodziewano się szeregu pozytywnych skutków Wystawy, nie wiadomo jednak, czy dało się je w ogóle odczuć (poza rozbudową infrastruktury Międzynarodowych Targów Poznańskich), ze względu na ogólnoświatowy kryzys gospodarczy, który już pod koniec roku dotarł również do Poznania.

Dziewięćdziesiąta rocznica największej imprezy wystawienniczej w Polsce międzywojennej zachęca do tego, aby spojrzeć na to wydarzenie z dystansu. Pozostało po niej dość dużo świadectw, które ukazują jej różnorodne aspekty. Na platformie Wielkopolskiej Biblioteki Cyfrowej umieszczono wiele materiałów ${ }^{6}$, które pozwalają, przynajmniej w części, zrekonstruować to, co działo się na Wystawie: jak rozmieszczono eksponaty, jakimi środkami i technikami przekazywano informacje, jaką pracę włożono w jej przygotowanie, oraz

${ }^{4}$ Oba budynki zaczęto wznosić dla Uniwersytetu Poznańskiego na początku lat 20. Z braku funduszy przez kilka lat stały niewykończone, aż w końcu, podczas przygotowań do Wystawy, prace mogły ponownie ruszyć.

${ }^{5}$ L. Ławnicki, Powszechna Wystawa Krajowa w 1929 roku (Urbanistyka), „Kronika Miasta Poznania" 1976, nr 1, s. 50.

${ }^{6}$ Lista tematów, wśród których można znaleźć wydawnictwa związane z Powszechną Wystawą Krajową, wyświetla się na stronie: https://www.wbc.poznan.pl/dlibra/indexsearch?rdfName $=$ Subject\&ipp $=60 \& p=0 \&$ startstr $=p \&$ filter $=$ powszechna $\quad($ dostęp: $\quad 30.11 .2019$ ). Jest to nowa odsłona WBC. Jeszcze do niedawna, na starej stronie, materiały dotyczące PWK były wydzielone w osobną kolekcję i pogrupowane tematycznie, czego jednak nie ma obecnie. Publikacji książkowych, broszur oraz prasy, w którym jako temat i słowa kluczowe przypisano Powszechną Wystawę Krajową jest w WBC ponad pięćset (szukanie poprzez „indeks”, następnie przeglądanie listy alfabetycznej "temat i słowa kluczowe”). Jeśli jednak zbiory są przeszukiwane poprzez ogólne hasło „Powszechna Wystawa Krajowa”, wyników wyszukiwania jest ponad 25 tys. Oznacza to, że część publikacji dotyczy Powszechnej Wystawy Krajowej z 1894 r. oraz że odnotowano każde wydanie prasy codziennej, gdzie w tekście pojawia się to wyrażenie. 
jak została przez jej współczesnych oceniona. Zeskanowane publikacje pochodzą głównie ze zbiorów Biblioteki Kórnickiej, Biblioteki Uniwersyteckiej oraz Biblioteki Raczyńskich. Trudno w jednym artykule przytoczyć je wszystkie, pragnę natomiast zwrócić uwagę na to, jak wydawnictwa te mogą wzbogacić wiedzę na temat Wystawy i ówczesnej Polski.

Jak dotąd, Powszechna Wystaw Krajowa doczekała się sporej, pięciotomowej monografii pod redakcją Stanisława Wachowiaka ${ }^{7}$, o której będzie mowa dalej. Było to wydawnictwo z 1930 r., które ma niewątpliwie ogromną wartość, wydaje się jednak, że inne wydawnictwa mogą również wiele wnieść.

Materiały z WBC są przede wszystkim drukami ówcześnie wydanymi. Można podzielić je na kilka grup: 1. Wydawnictwa Pewuki, 2. Wydawnictwa przygotowane z okazji Pewuki, 3. Fotografie, 4. Prasa wielkopolska i ogólnopolska. Strona Wielkopolskiej Biblioteki Cyfrowej grupuje zbiory w wersji cyfrowej nieco inaczej: 1. Wystawa, 2. Wystawcy, 3. Wydano z okazji PWK, 4. Pewuka na fotografiach, 5. Pewuka w wielkopolskiej prasie, 6. Pewuka $\mathrm{w}$ prasie krajowej, 7. O Wystawie inaczej, 8. Pewuka w zbiorach innych bibliotek cyfrowych.

W grupie dotyczącej Wystawy znajdują się przede wszystkim wszelkie książki i broszury dotyczące drogi do powstania Pewuki oraz te ułatwiające zwiedzanie. Udostępniono więc pięciotomowe dzieło Wachowiaka ${ }^{8}$. Jest ono podstawowym wydawnictwem, które obszernie opisuje starania o Wystawę, jej przebieg i zaangażowanie poszczególnych wystawców. Są także przewodniki poświęcone temu, jak i co, ale przede wszystkim, dlaczego należy zwiedzać na Powszechnej Wystawie. Jak pisano w jednej z takich broszur:

„Powszechna Wystawa Krajowa w r. 1929 tylko wtenczas spełni całkowicie swe zadanie, gdy ją zobaczy cała Polska. Jeżeli cel ten ma być osiągnięty, wieść o Wystawie dotrzeć musi do najodleglejszych zakątków kraju, do każdej zagrody włościańskiej i najmniejszego domku robotniczego. Wiele w tym względzie zdziałać może i zdziała prasa, lecz główne zadanie [...] przypadnie w udziale żywemu słowu, które w postaci odczytów i pogadanek uświadamiać będzie jak najszersze warstwy społeczeństwa o znaczeniu Powszechnej Wystawy Krajowej oraz o konieczności jej zwiedzenia.

Pragnąc przyjść z pomocą tym wszystkim, którzy z poczucia obywatelskiego czynny zechcieliby brać udział w tej akcji [...], wypuszczamy niniejszą

\footnotetext{
${ }^{7}$ Nie ma współczesnej monografii, która w pełni, z historycznego dystansu podejmowałaby się zadania oceny Wystawy i jej znaczenia, zarówno w warstwie edukacyjnej, jak i jej wpływu na rozwój poszczególnych gałęzi przemysłu. Nie robi tego również praca M.R. Bombickiego, PWK - Powszechna Wystawa Krajowa w Poznaniu 1929, Poznań 1992, choć w przystępny sposób pokazuje czytelnikom sześćdziesiąt lat później, czym była Wystawa.

${ }^{8}$ Powszechna Wystawa Krajowa w Poznaniu w roku 1929, red. S. Wachowiak, t. I-V, Poznań 1930.
} 
broszurkę, która wszechstronnie o całokształcie spraw PWK i daje materiał, umożliwiający opracowanie i wygłoszenie szeregu odczytów [...]"9.

Ważną publikacją było czasopismo „Echo Powszechnej Wystawy Krajowej", wydawane przez Zarząd Wystawy. Pierwszy numer ukazał się w styczniu 1928 r. Przez ponad rok był to miesięcznik, ale od kwietnia 1929 r. zaczął ukazywać się częściej i nie zawsze regularnie. Ostatni numer wyszedł na początku października, zaraz po zamknięciu Wystawy. „Echo” miało do odegrania rolę propagandową. Jego celem była przede wszystkim agitacja za tym, aby odwiedzić Pewukę. Publikowano tam wiele przemówień, reportaży z poszczególnych odcinków pracy i sprawozdań z gotowych już ekspozycji. Zamieszczano również artykuły o charakterze edukacyjnym, które informowały np. o kondycji poszczególnych gałęzi przemysłu w Polsce. Periodyk jest dzisiaj znakomitym źródłem do dziejów i przebiegu Pewuki także ze względu na bogaty materiał ikonograficzny.

Do wydawnictw Pewuki, a jednocześnie takich, które dotyczą wystawców, należy Katalog główny ${ }^{10}$. Lwią część Wystawy stanowił przemysł i wszelkie jego gałęzie, stąd zbudowano na jego potrzeby wielkie pawilony, np. włókiennictwa czy przemysłu ciężkiego lub metalowego, oraz niewielkie, często bardzo ciekawe architektonicznie (przykładem może być np. pawilon witraży czy czekolady Fuchs) dla drobnych wystawców. Katalog główny to jedna z najciekawszych publikacji, a jednocześnie raczej nieudostępniana w innych bibliotekach. Oczywiście, nie obejmuje całości pawilonów, ale ich ogromną większość. Każdy pawilon, który znajduje się w Katalogu ma swój plan i wykaz stanowisk. Dzięki temu możliwe jest zrekonstruowanie położenia poszczególnych eksponatów. Szukanie ułatwiają indeks wystawców i indeks eksponatów. Przy każdym wystawcy znajdują się dane teleadresowe oraz informacja o tym, co wystawiał. Publikację wzbogacono licznymi reklamami, które miały zachęcać gości do odwiedzin na Wystawie. Daje on przede wszystkim panoramiczny obraz istniejących wówczas w Polsce przedsiębiorstw i faktycznego potencjału wytwórczego.

Komisja Wystawy Rządowej na P.W.K. wydała własny katalog ${ }^{11}$. Pałac Rządowy ulokowany był w Collegium Chemicum Uniwersytetu Poznańskiego. Omówione jest prawie każde ministerstwo (łącznie z tymi, które miały własne pawilony, jak Ministerstwo Komunikacji, Poczt i Telegrafów, Rolnictwa, Reform Rolnych), w taki sposób, że najpierw następuje zawsze

${ }^{9}$ Co każdy wiedzieć powinien o Powszechnej Wystawie Krajowej w Poznaniu w r. 1929?, Poznań 1929, s. 2.

${ }^{10}$ Katalog główny: obejmuje przemyst, samorządy, wychowanie fizyczne i instytucje kulturalno-oświatowe, wydawnictwo Powszechnej Wystawy Krajowej w Poznaniu, 1929.

${ }^{11}$ Wystawa Rzadowa na Powszechnej Wystawie Krajowej, Poznań 1929. 
plan rozmieszczenia danego ministerstwa w budynku, potem rys historyczny resortu, a następnie wykaz sal i ich opis.

Ministerstwo Spraw Zagranicznych wydało oprócz tego własny kata$\log ^{12}$, który opisuje historię Ministerstwa, wymienia wszystkich ministrów od 1918 r., wymienia urzędy zagraniczne podległe MSZ, opisuje służbę konsularną i udział Polski w życiu międzynarodowym. Jego największą zaletą jest jednak spis tablic statystycznych oraz eksponatów i dokumentów zamieszczonych na Wystawie, a trzeba wspomnieć, że były to skarby z polskich archiwów i muzeów, dotyczące polskiej dyplomacji aż od średniowiecza.

Podobnie postąpiły Ministerstwo Skarbu ${ }^{13}$ i Ministerstwo Wojny ${ }^{14}$. Katalog pierwszego resortu składa się z dwóch części: I. Rachunków skarbowych dawnej Rzeczypospolitej, II. Skarbu w państwach polskich XIX wieku. Całość opracował Józef Siemieński, uznany historyk i archiwista, który dobrał jako ilustracje, zamieszczone zresztą w katalogu, archiwalne dokumenty dotyczące polskiego skarbu i podatków, począwszy od przywileju koszyckiego w 1374 r.

Drugi katalog opisuje kolejne sale, które poświęcone były dwóm głównym tematom: historii wojskowości i przemysłowi wojennemu. Była tam sala poświęcona zarówno legionom, jak i powstaniom. Bardzo ciekawie przedstawiają się fotografie prezentujące makiety, np. wojskowej piekarni.

Niezwykle ważnym wydawnictwem był Katalog Działu Sztuki ${ }^{15}$. Wystawa zaprezentowana w Pałacu Sztuki, jakim stał się na cztery miesiące budynek Anatomii Uniwersytetu Poznańskiego, była ozdobą Pewuki. Prezentuje on całość ówczesnego stanu polskich sztuk plastycznych. Katalog wymienia wszystkie zaprezentowane prace, uwzględniając podział na piętra i konkretne grupy artystyczne. Załączony aneks ilustruje oczywiście tylko część prac, jednak ich dobór jest jak najbardziej przekrojowy.

Oprócz Katalogu opublikowano także opracowanie na temat polskiej sztuki w latach 1918-1928. Mieczysław Treter swoją narracją cofa się jednak w czasie, gdy pisze o znaczeniu polskiej sztuki - jej misji społecznej i politycznej ${ }^{16}$. Komentuje również ekspozycję, którą sam koordynował, wyrażając zdanie, że jeśli są na niej punkty słabe, to dlatego, że takie elementy zawiera sztuka polska ${ }^{17}$. Praca ta jest opracowaniem historycznym, które miało być wartością do-

${ }^{12}$ Katalog Wystawy Ministerstwa Spraw Zagranicznych, Warszawa 1929.

${ }^{13}$ Dziat Staropolski Ministerjum Skarbu na Powszechnej Wystawie Krajowej w Poznaniu 1929, oprac. J. Siemieński, Warszawa 1929.

${ }_{14}$ Wojsko na Powszechnej Wystawie Krajowej w Poznaniu, maj-wrzesień 1929, Główna Księgarnia Wojskowa, Warszawa 1929.

${ }^{15}$ Katalog Działu Sztuki, Powszechna Wystawa Krajowa, Poznań 1929.

${ }^{16}$ M. Treter, Sztuka polska i polskie życie: (dziat sztuki na P.W.K. w Poznaniu i dziesięciolecie 1918-1928), Kraków-Warszawa 1929, s. 9.

${ }^{17}$ Tamże, s. 4. 
daną dla gości zainteresowanych zapoznaniem się z polską sztuką. Takie podejście do wydawnictwa informacyjnego pokazuje, że Wystawa miała przede wszystkim cel edukacyjny, a przekaz informacji następował nie tylko środkami wizualnymi, ale również poprzez bardziej pogłębione opracowanie.

Katalogi dla wystawy prezentowanej w pawilonie Prasy i Książki (nr 40) zostały podzielone na dwa wydawnictwa. Wystawa Książki ${ }^{18}$ obejmowała 22 stoiska. Katalog omawia po kolei (z numerami stoisk) wystawców i krótko ich charakteryzuje, nie podaje niestety, co każdy z nich prezentował. Mimo wszystko jest to zbiorcze opracowanie ówczesnego rynku księgarskiego. Nie brakowało więc krótkiego rysu historycznego Zakładu Narodowego im. Ossolińskich we Lwowie ${ }^{19}$, Związku Księgarzy Polskich i Polskiego Towarzystwa Wydawców Książek ${ }^{20}$, wydawnictwa Nasza Księgarnia ${ }^{21}$ czy Drukarni i Księgarni Św. Wojciecha w Poznaniu ${ }^{22}$. Nie należy mylić tej wystawy z działem Piękna Książka w Pałacu Sztuki, która (choć niektórzy wydawcy się powtarzają) miała za zadanie przedstawić artystyczną produkcję wydawniczą jako jedną z gałęzi rzemiosła zdobniczego i prezentowała w związku z tym także artystów-grafików, drukarzy i introligatorów ${ }^{23}$.

Katalog wystawy Prasy ${ }^{24}$ bardzo dobrze i wyczerpująco oddał to, co zwiedzający mogli zobaczyć. Ekspozycję, podzieloną na dwie zasadnicze części ${ }^{25}$, rozpoczynał Dział Historyczny, czyli dzieje prasy w Polsce przedrozbiorowej i w epoce zaborów. Wykresy i mapy pokazywały: początki nowinkarstwa (od 1555 r.), początki prasy periodycznej i rozwój prasy. Nie zabrakło również wydawnictw prasowych od 1517 r. z podziałem na poszczególne miasta. Przedstawiono również prasę polską na emigracji oraz prasę współczesną, znów za pomocą wykresów, map i przykładowych wydawnictw. Drugą zasadniczą częścią była wystawa bieżąca. Katalog podawał, na jakim stoisku poszczególne czasopisma mają własne wystawy. Załączone zdjęcia pozwalają zobaczyć, że stoiska były nierzadko zorganizowane z rozmachem.

Ogromnym działem Pewuki było rolnictwo, podzielone na kilka pawilonów, poświęconych m.in.: Ministerstwu Rolnictwa, produkcji roślinnej i zwierzęcej, maszynom, organizacjom, nawozom sztucznym i zabudo-

${ }^{18}$ Przewodnik po Grupie „Książk" Powszechnej Wystawy Krajowej w Poznaniu 1929, ułożył Jan Muszkowski, Warszawa 1929.

${ }^{19}$ Tamże, s. 14-16.

${ }^{20}$ Tamże, s 19-25.

${ }^{21}$ Tamże, s. 32-33.

22 Tamże, s. 43-44.

${ }^{23}$ Katalog Dziatu Sztuki..., s. 197-199.

${ }^{24}$ Katalog Wystawy Prasy na Powszechnej Wystawie Krajowej w Poznaniu, Wydawnictwo Polskiego Związku Wydawców Dzienników i Czasopism, Warszawa 1929.

${ }^{25}$ Nie jest to bardzo precyzyjnie określone w katalogu, dopiero wyraźniej to zaznacza artykuł S. Kauzika, Wystawa Prasy, [w:] Powszechna Wystawa Krajowa w Poznaniu w roku 1929, dzieło zbiorowe pod kierownictwem S. Wachowiaka, t. IV, Poznań 1930, s. 303-316. 
waniom gospodarczym. Sam katalog był również sporym wydawnictwem, podzielonym na części. Podczas Pewuki na terenie "E” bardzo często odbywały się wystawy, np. zwierząt hodowlanych, koni i psów rasowych, a nawet ryb. Część ogólna katalogu wystawy rolniczej została wydana podobnie jak Katalog główny. Każdy pawilon został rozrysowany z zaznaczeniem poszczególnych stoisk, które omówione są dalej. Można więc dokładnie stwierdzić, kto, skąd i co wystawiał. Pozostałe części dotyczą wystaw czasowych. Wydaje się to mało interesujące i wówczas wydane raczej ze względu na samych wystawców, ale znowu trzeba przyznać, że publikacja daje obraz działalności ówczesnych hodowców i właścicieli zwierząt w Polsce ${ }^{26}$.

Dwa bardzo ciekawe wydawnictwa dotyczą pawilonu Związku Ziemian, który ulokowany był również na terenach dotyczących rolnictwa. Jednym jest pięknie wydany katalog27, a drugi wydaje się stanowić jego załącznik, ale tego nie wiadomo na pewno, gdyż jest zbiorem tablic i wykresów ${ }^{28}$. Katalog zapowiada już na początku, że „,W pawilonie umieszczone są eksponaty ilustrujące rolę ziemiaństwa w dziedzinie społecznej, gospodarczej i kulturalnej"29. Omówiona jest szczegółowo każda sala i eksponaty, które się w niej znajdują, łącznie z tym, kto wykonał dane dzieło sztuki, kto jest właścicielem np. stołu dębowego, na którym podpisano decyzję o powstaniu styczniowym w $1863 \mathrm{r}$. Była to ekspozycja niezwykle bogata, dość powiedzieć, że Pałac w Wilanowie wypożyczył m.in. wielki namiot polowy Wezyra Kara Mustafy, zdobyty przez Jana III Sobieskiego w 1683 r. Prezentowano również broń, zbroje i pamiątki po polskich szlachcicach, co doskonale widać na załączonych zdjęciach. Z kolei kolekcja wykresów, które były eksponowane na Wystawie, przedstawiała udział ziemian w różnych sferach życia w Polsce, szczególnie politycznej, wojskowej, stowarzyszeniowej i gospodarczej, oraz dane dotyczące prywatnych gospodarstw rolnych i uprawy gruntów. Kolekcja ta przynosi ciekawe statystyki, które dzisiaj mogłyby być wykorzystane jako źródła dotyczące ówczesnego życia ziemiaństwa i rolnictwa. Odsłania to nieoczywisty aspekt wydawnictw związanych z Pewuką - mogą być one zarówno tekstami źródłowymi, jak i opracowaniami historycznymi, dotyczącymi nie tylko Wystawy, ale także Polski w okresie dwudziestolecia międzywojennego.

Przy okazji Pawilonu Ziemian warto wspomnieć o ziemiankach i włościankach. One również chciały mieć swój pawilon (był pawilon Pracy Kobiet,

${ }^{26}$ Ciekawym przykładem jest wystawa psów, z katalogu której można się dowiedzieć m.in., że psy rasowe wystawiali np.: Korpus Ochrony Wojsk Pogranicza, Tresura Psów Policyjnych Poznań-Cytadela lub Dyrekcja Kolei Państwowych. Katalog rolniczy, cz. III, Wystawa Psów Rasowych od 1-4 czerwca 1929 roku w halach zwierzęcych, Poznań 1929, s. 7.

${ }^{27}$ Katalog Pawilonu Zwiazku Ziemian, Wydawnictwo Rady Naczelnej Organizacyj Ziemiańskich z okazji Powszechnej Wystawy Krajowej w roku 1929, Poznań 1929.

${ }^{28}$ Pawilon Zwiazku Ziemian, Rady Naczelnej Organizacyj Ziemiańskich z okazji Powszechnej Wystawy Krajowej w roku 1929, Warszawa 1929.

${ }^{29}$ Katalog Pawilonu Zwiazku Ziemian, s. 9. 
ale ziemianki stwierdziły, że ich praca i rola społeczna polega nieco na czym innym $\left.{ }^{30}\right)$, aby pokazać kobiety $\mathrm{w}$ środowisku wiejskim. To wydawnictwo było jednak, jak same pisały, pamiętnikiem prac nad pawilonem i przebiegu wystawy, wydanym zresztą już po Pewuce. Zawierał on również charakterystykę prac społecznych i ekonomicznych, jakich podejmowały się Koła Ziemianek. Na tym się jednak nie kończyło, tutaj bowiem również czytelnik otrzymywał opis poszczególnych sal i eksponatów.

Wydawnictwa o charakterze katalogowym dają pewien obraz (niecałościowy) zorganizowania ekspozycji, przede wszystkim tego, jakie udało się zebrać eksponaty. Dzieło Wachowiaka, jakkolwiek ogromnie szczegółowe, nie jest aż tak precyzyjne, by podawać kolejność zgromadzonych materiałów, nie było to zresztą jego założeniem. Poza tym dają faktycznie wyobrażenie tego, co się w Polsce wówczas produkowało, gdzie Polacy się zrzeszali, jak funkcjonowały poszczególne ministerstwa, oświata, jakie role odgrywały kobiety.

Wszelkie katalogi traktowano jako okazję do przekazania idei, jaka towarzyszyła Pewuce. Co ciekawe, niektóre wydawnictwa są dwujęzyczne, jakby ich autorzy pragnęli wyjść naprzeciw oczekiwaniom zagranicznych gości. Niemal wszystkie były skierowane do osób odwiedzających Wystawę, nie można jednak wykluczyć, że w określonych środowiskach traktowano je jako pamiątki po wysiłku organizacyjnym, skierowane raczej do tych, którzy się tego wysiłku podjęli. Jednocześnie w treść tych materiałów często włączano opracowania historyczne, które dzisiaj mogą służyć badaczom, nie mówiąc już o tych fragmentach, które charakteryzowały elementy ówczesnej, polskiej rzeczywistości, nierzadko ujmując je w diagramy i statystyki.

Wspomnieć by wypadało, że zamieszczony na WBC Katalog wystawy Zwiazku Miast Polskich na Międzynarodowym Targu w Poznaniu nie dotyczy Pewuki, a Targu z 1925 r. Targ ten był zdecydowanie przełomowy dla historii Międzynarodowych Targów i być może z tego względu znalazł się w dziale Powszechna Wystawa Krajowa, inaczej mógłby zginąć w masie zdigitalizowanych materiałów.

Z okazji Wystawy wydano: przewodniki po Poznaniu, różnego rodzaju księgi pamiątkowe (np. Wszechsłowiańskiego Zjazdu Śpiewaczego), programy zjazdów, wiele broszur, np. na temat urządzania wycieczek, krótką historię poczty w Polsce ${ }^{31}$ czy informator o przemyśle włókienniczym ${ }^{32}$. Dwie ostatnie pozycje są bardzo ciekawe. Historia poczty ukazana jest od czasów

${ }^{30}$ Pawilon Ziemianek $i$ Wtościanek na Powszechnej Wystawie Krajowej w Poznaniu w R. 1929, Wydawnictwo Rady Naczelnej Ziemianek, Warszawa 1930, s. 7.

${ }^{31}$ Krótki Zarys Poczty w Polsce i Taryfa Pocztowa, Nakładem Dyrekcji Poczt i Telegrafów w Poznaniu, 1929.

32 Przemyst włókienniczy, Łódź 1929. 
średniowiecznych, ale główny ciężar położony został na jej kształtowaniu się po 1918 r. W kolejnej części mowa jest o różnych typach przesyłek z podaniem taryfy pocztowej.

Druga publikacja skupiała się na odbudowie przemysłu włókienniczego po zniszczeniach wojennych i problemach, z jakimi musieli się zmagać przedsiębiorcy. Pokazuje to zresztą, że sytuacja gospodarcza ulegała wahaniom i pomimo dużego rozwoju na początku lat dwudziestych, włókiennictwo zmagało się później z zahamowaniem eksportu tkanin ${ }^{33}$. Broszura zawiera wykaz wszystkich firm, które zajmowały się w 1929 r. przemysłem włókienniczym i prezentuje historię tych największych oraz najprężniej działających, jak Zakłady Scheiblera i Grohmana, Biedermanna, Poznańskiego.

W zbiorach WBC znajdują się również materiały, które ukazują Wystawę i są jej wyjątkowym świadectwem. Jednym z nich jest album ze zdjęciami wybitnego, poznańskiego fotografa - Romana Stefana Ulatowskiego, który jest własnością Biblioteki Uniwersyteckiej, a drugim - album ze zdjęciami Władysława Kowalczyka, podarowany Cyrylowi Ratajskiemu, znajdujący się w Bibliotece Raczyńskich (sygnatura F XIV 28). Zdjęcia Ulatowskiego zostały pokolorowane, natomiast Kowalczyka wydrukowane w sepii, na beżowym papierze. Wiadomo, że pawilony były barwnie pomalowane, więc kolorowy album daje wyobrażenie o tym, jak mogła wyglądać całość. Album Kowalczyka jest dość duży, ale przez to bardzo pomaga poznać Wystawę od strony architektonicznej i urbanistycznej. Zdjęcia są nie tylko wyraźne, mają duże walory artystyczne, ale przede wszystkim ukazują niemal wszystkie pawilony, z czego dużą część wewnątrz. Z pięciotomowej publikacji Stanisława Wachowiaka oraz „Echa Powszechnej Wystawy Krajowej” wynika, że były one często wykorzystywane w oficjalnych wydawnictwach.

Poza albumami WBC prezentuje inne, pojedyncze fotografie, tych jednak jest niedużo. Zaznaczono natomiast, że więcej zdjęć jest zaprezentowanych na stronach innych bibliotek cyfrowych. Rzeczywiście, w podanych linkach znajdują się czasopisma wydawane w całej Polsce, jak np. „Rzeczy Piękne”, ogłaszane nieregularnie w okresie międzywojennym w Krakowie, które zawierają, na przestrzeni kilku numerów, różne oceny poszczególnych części Wystawy z uwzględnieniem technik wystawienniczych i jakości prezentowanych eksponatów. Innym czasopismem jest "Architektura i Budownictwo", które było wydawane w Warszawie przez grupę architektów z wielu miast Polski. W tym wypadku również można zauważyć, że specjaliści na gorąco oceniali Wystawę, szczególnie pod względem architektonicznym.

Nie mogło w przeglądzie publikacji cyfrowych zabraknąć prasy, przede wszystkim poznańskiej i wielkopolskiej, jak: „Kurier Poznański”, „Dziennik Poznański”, „Goniec Wielkopolski”, „Ilustracja Poznańska”, „Samochód

33 Tamże, s. 4. 
Ilustrowany”, „Tydzień Radjowy” czy „Wielkopolska Ilustracja”. Z prasy ogólnokrajowej zamieszczono przede wszystkich numery dwutygodnika „Ziemia”. Wybrane numery zawierały najczęściej reportaże i wzmianki z otwarcia oraz zamknięcia Wystawy, ewentualnie z poszczególnych zjazdów, wyjątkowo ciekawych ekspozycji czy wizyt specjalnych gości. Dzięki temu można zapoznać się z opiniami ówczesnych na temat Pewuki i tego, co się na niej działo. Szczególnie cenne są opinie zagraniczne, jak np. wypowiedzi międzynarodowych dyplomatów z Wielkiej Brytanii i Jugosławii, które przedrukował „Kurier Poznański” ${ }^{34}$. To jednak nie wszystko - uważny czytelnik zauważy w prasie codziennej drobne informacje dotyczące np. repertuaru teatrów, kursu wymiany walut, bieżącego kalendarza imprez, cen kwater, prognozy pogody, incydentów w terenie wystawy - tych śmiesznych i tych dramatycznych. „Kurier Poznański” miał w swoim porannym wydaniu część „Kurier Wystawowy”. Nierzadko jego dziennikarz przytaczał rozmowy zasłyszane na terenach wystawowych, szczególnie w ramach rubryki "Z lornetką na PWK". Odbiorcami lokalnej prasy mieli być nie tylko mieszkańcy Poznania. Jest rzeczą zrozumiałą, że chciano zachęcić przyjezdnych do zwiedzania miasta przy okazji Wystawy i ułatwić im poruszanie się oraz organizację swojego pobytu.

Powszechna Wystawa Krajowa jako wydarzenie była przeglądem sił wytwórczych całego narodu, miała ogromną wartość propagandową i prezentowała prawdopodobnie inny obraz Polski, niż mieli zagraniczni goście. Organizatorzy zrealizowali również zapowiadany cel edukacyjny, dała ona bowiem możliwość ogromnej rzeszy polskich obywateli zdobycia nieprzeciętnej wiedzy o własnym kraju.

Doprowadziła wreszcie, poprzez wydawane przy jej okazji publikacje, do podsumowań, które dla ówczesnych były potwierdzeniem wielkiego wysił$\mathrm{ku}$, jaki dokonał się w ciągu dziesięciu lat od odzyskania niepodległości. Dla współczesnego czytelnika są one świadectwami tamtej epoki i niesłychanie ciekawymi źródłami do badania rozwoju społeczno-gospodarczego z dłuższej perspektywy oraz niejako „oprowadzają" po Wystawie, której nie można już dziś zobaczyć.

\section{Bibliografia}

Bombicki M.R, PWK - Powszechna Wystawa Krajowa w Poznaniu 1929, Poznań: Ławica, 1992.

Co każdy wiedzieć powinien o Powszechnej Wystawie Krajowej w Poznaniu w r. 1929?, Poznań:

Wydawnictwo Powszechnej Wystawy Krajowej, 1929.

Dyplomaci cudzoziemscy o PWK, „Kurier Poznański” 1929, nr 244, s. 3.

34 „Kurier Poznański” z 29 maja 1929, s. 3. 
Dział Sztuki. Powszechna Wystawa Krajowa, Poznań 1929.

Katalog główny: obejmuje przemyst, samorzady, wychowanie fizyczne i instytucje kulturalno-oświatowe, Wydawnictwo Powszechnej Wystawy Krajowej w Poznaniu, Poznań 1929.

Katalog Pawilonu Związk Ziemian, Rada Naczelna Organizacyj Ziemiańskich, Poznań 1929.

Katalog rolniczy cz. III, Wystawa Psów Rasowych od 1-4 czerwca 1929 roku w halach zwierzęcych, Wydawnictwo Powszechnej Wystawy Krajowej, Poznań 1929.

Katalog Wystawy Ministerstwa Spraw Zagranicznych, Warszawa 1929.

Katalog Wystawy Prasy na Powszechnej Wystawie Krajowej w Poznaniu, Wydawnictwo Polskiego Związku Wydawców Dzienników i Czasopism, Warszawa 1929.

Kauzik S., Wystawa Prasy, [w:] Powszechna Wystawa Krajowa w Poznaniu w roku 1929, dzieło zbiorowe pod kierownictwem S. Wachowiaka, t. IV, Drukarnia Świętego Wojciecha Poznań 1930, s. 301-316.

Krótki Zarys Poczty w Polsce i Taryfa Pocztowa, Dyrekcja Poczt i Telegrafów w Poznaniu, Poznań 1929.

Litewka P., Powszechna Wystawa Krajowa (16 maja - 30 września 1929), Część pierwsza, „Kronika Miasta Poznania" 1979, nr 2, s. 37-54.

Ławnicki L., Powszechna Wystawa Krajowa w 1929 roku (Urbanistyka), „Kronika Miasta Poznania” 1976, nr 1, s. 45-60.

[Muszkowski J.], Przewodnik po Grupie „Książk” Powszechnej Wystawy Krajowej w Poznaniu 1929, Polskie Towarzystwo Wydawców Książek, Warszawa 1929.

Pawilon ZiemianekiWtościanekna Powszechnej Wystawie Krajowej w Poznaniu R. 1929, Wydawnictwo Rady Naczelnej Ziemianek, Warszawa 1930.

Powszechna Wystawa Krajowa 1929: Przemyst włókienniczy, Administracja tygodnika „Prawda”, Łódź 1929.

[Wachowiak S.], Powszechna Wystawa Krajowa w Poznaniu w roku 1929, Drukarnia Świętego Wojciecha, Poznań 1930.

[Siemieński J.], Dział Staropolski Ministerjum Skarbu na Powszechnej Wystawie Krajowej w Poznaniu 1929, Warszawa 1929.

Treter M., Sztuka polska i polskie życie: (dziat sztuki na P.W.K. w Poznaniu i dziesięciolecie 1918-1928), Towarzystwo Wydawnicze w Warszawie, Kraków-Warszawa 1929.

Wachowiak S., Rys historyczny, [w:] Powszechna Wystawa Krajowa w Poznaniu w roku 1929, red. S. Wachowiak, t. I, Drukarnia Świętego Wojciecha, Poznań 1930.

Wachowiak S., Czasy, które przeżyłem, Oficyna Wydawnicza Interim, Warszawa 1991.

Wojsko na Powszechnej Wystawie Krajowej w Poznaniu, maj-wrzesień 1929, Główna Księgarnia Wojskowa, Warszawa 1929.

Wystawa Rządowa na Powszechnej Wystawie Krajowej, Komisarjat Wystawy Rządowej P.W.K., Poznań 1929. 
Magdalena Heruday-Kiełczewska

\title{
Materiały dotyczące Powszechnej Wystawy Krajowej w 1929 r. w zbiorach Wielkopolskiej Biblioteki Cyfrowej
}

\begin{abstract}
Streszczenie
Powszechna Wystawa Krajowa, zorganizowana w Poznaniu w 1929 r. była największym wydarzeniem wystawienniczym w historii II Rzeczypospolitej. Mając za cel pokazanie dorobku niepodległej Polski, była przeglądem jej osiągnięć w zakresie przemysłu, polityki, kultury, rolnictwa. Celem artykułu jest przedstawienie najważniejszych materiałów - katalogów, książek, fotografii, czasopism, które zostały wydane z okazji Wystawy, lub które o niej wspominają. Analiza wybranych publikacji pozwala zapoznać się szczegółowo z treściami prezentowanymi na poszczególnych ekspozycjach. Wiele publikacji miało również odgrywać rolę edukacyjną. Część z nich była opracowaniami historycznymi, a część stanowi dziś świadectwo o ówczesnej sytuacji społeczno-polityczno-kulturalnej w Polsce, dzięki czemu mogą być uznane jako źródła do badań historycznych z dzisiejszej perspektywy.
\end{abstract}

Słowa kluczowe: Powszechna Wystawa Krajowa, Wielkopolska Biblioteka Cyfrowa, Poznań, digitalizacja, katalogi

Magdalena Heruday-Kiełczewska

\section{Materials regarding the Polish General Exhibition in 1929 in the collection of the Greater Poland Digital Library}

\begin{abstract}
The Polish General Exhibition organized in Poznań in 1929 was the biggest exhibition in the history of the Second Polish Republic. Its goal was to showcase the achievements of independent Poland, and present a review of its accomplishments in the areas of industry, politics, culture, and agriculture. The article aims at presenting the most important materials: catalogs, books, photographs, and magazines, which were published to celebrate the Exhibition or contain references to it. The analysis of selected publications allows one to gain detailed insights into the content of particular displays. Many publications were also meant to play an educational role. Some of them were historical studies, and some are now the testimony of the social, political, and cultural situation in Poland back then, which means they can be treated as sources for historical research from the contemporary point of view.
\end{abstract}

Keywords: Polish General Exhibition, Greater Poland Digital Library, Poznań, digitalization, catalogs 